Werner, M. ; Schäfer, A. I. (2007) Social aspects of a solar-powered desalination unit for remote Australian communities,

Desalination, Volume 203, Issues 1-3, 5 February 2007, Pages 375-393

doi:10.1016/j.desal.2006.05.008

\section{Social Aspects of a Solar-Powered Desalination Unit for \\ Remote Australian Communities}

M. Werner ${ }^{1}$, A. I. Schäfer ${ }^{2}$

${ }^{1}$ School of Civil, Mining \& Environmental Engineering, University of Wollongong, NSW 2522, Australia \begin{tabular}{l} 
Tel. +61 (2) $42214588 ;$; Fax +61 (2) 4221 3238; email: maw07@uow.edu.au \\
\hline
\end{tabular}

${ }^{2}$ School of Engineering \& Electronics, University of Edinburgh, EH9 3JL, United Kingdom

The technical, economic and environmental aspects of small scale desalination units powered by renewable energies for remote areas have received considerable attention in recent years. However, social aspects of such units have often been neglected resulting in recent years. However, social aspects of such units have often been neglected resulting in osmosis solar installation (ROSI) to be integrated at a number of different sites in Central osmosis solar installation (ROSI) to be integrated at a number of different sites in Central
Australia. Performance is evaluated against attributes of social sustainability, such as the unit's capacity to meet community water needs (both quality and quantity), the human resources available to operate and maintain the unit and the community response to the unit. From this preliminary evaluation, a number of operation and management recommendations relating to membrane choice, recovery rate and maintenance provision are made to ensure the potential offered by ROSI is fulfilled in a socially sustainable manner. Areas requiring further research are also identified.

Keywords: Remote communities; sustainable technology; reverse osmosis; solar energy; water users; community response; social aspects; maintenance

\section{Introduction}

The potential for use of small-scale membrane desalination units powered by renewable energy in remote communities has received increasing attention in recent years [1-3]. However the focus of the literature has largely been upon the technical, economic and environmental aspects of such units. Social aspects have received less consideration, even though they are of considerable importance to the successful and sustainable operation of any technology, but particularly those in remote areas. For example, membrane technology is prone to membrane fouling which requires careful management in remote locations. Problems like this can give the wech requen give the technology a poor reputation which does not reflect on the technology itself, but rather the way it has been implemented and is managed.

According to the United Nations Development Program (UNDP), over 1 billion people lack access to clean drinking water [4]. To solve these problems, innovative technologies are required and renewable-powered membrane desalination units have a promising role to play in both developing and developed countries [5]. However, in order to be socially sustainable, such technologies must:

- be accepted by the community,

- meet their water needs, and

- be within their capacity to operate and maintain.

The introduction of even simple desalination technologies has failed where these criteria are not met, as shown by the experience in Greece where solar stills were destroyed by a community even though they had been donated at no cost to the users [6].

The social aspects of desalination technologies should ideally be considered before a new technology is introduced, by examining the water uses and needs of a community, the human resources available for the management and operation of a membrane desalination unit, and the response of the broader community to a prototype of such a unit. A field trip for testing of the reverse osmosis solar installation (ROSI) in Australia has provided the opportunity to investigate these social factors using social science research methods such as small-scale interviews and surveys, and theoretical insights from the fields of appropriate and sustainable technologies (both described below). The practical application of these theories to the case sudy of ROSt bein communities has resulted in an assessment of the prototype's suitability, and the identification of strategies to contribute to the successful development and implementation of renewable-powered desalination units in remote areas.

\section{Background}

Since the purpose of this paper is to explore the social aspects of this unit a brief technical overview of the unit will be followed by some information about the water situation in Central Australia and the theoretical background to this approach.

\subsection{Central Australia Social and Environmental Background}

The majority of Central Australia is classified as 'very remote' by the Australian Bureau of Statistics, as shown in Figure 1. This classification is based on a calculation of the distance by road to major service centres, and very remote areas are classified as having "very little accessibility of goods, services and opportunities for social interaction" [11]. Only $0.9 \%$ of Australia's population lives in such areas, and a high proportion of this remote population is Indigenous [12]. There are an estimated 1030 small Indigenous communities in very remote Australia [13]. These communities usual have essentia services such as power and water supplied through a community council, which also employs an Essential Services Officer (ESO) to look after a number of small sites that are the council's responsibility. There are also a number of roadhouses, which sell fuel and often also food to travellers, farms (predominantly for beef cattle but also used for crop cultivation), and small towns which act as service and administrative centres for surrounding farms and Indigenous communities.

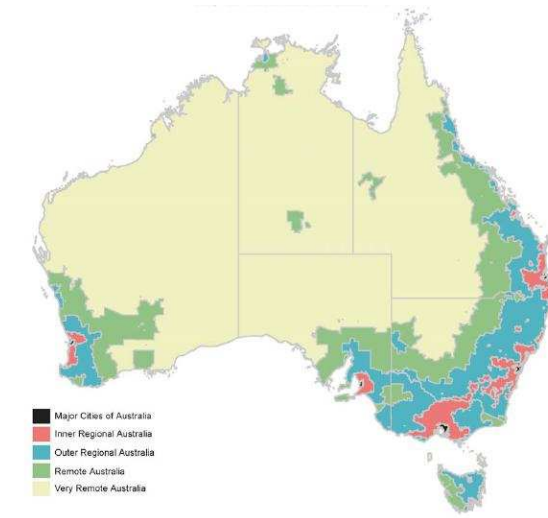

Figure 1. Australia classified by Remoteness Area [14, Appendix C, p. C4]

ROSI is of interest in these contexts in Central Australia due to the low rainfal received (Figure 2), the high number of hours of average daily sunshine (Figure 3 ) and reliance upon groundwater accessed through bores as a water source. Approximately $67 \%$ of Indigenous communities with a population of less than 100 people use bore water for their supply [13]. The quality of groundwater in Central Australia is variable, but salinity and hardness are commonly reported problems.

Salinity can reduce the palatability of water and reduced water consumption may lead to health problems such as dehydration, kidney dysfunction, and hypertension [15]. High levels of hardness $\left(\mathrm{CaCO}_{3}\right)$ can also affect the palatability of water, and lead to mineral build-up which blocks pipes or reduces flows. Other water sources such as rivers or 
Werner, M. ; Schäfer, A. I. (2007) Social aspects of a solar-powered desalination unit for remote Australian communities,

rainwater are accessed when possible, and some communities are connected to a town water supply which is treated and purified to meet the Australian Drinking Water Guidelines. However when alternative water sources are not available the consumption of poor quality groundwater can have significant negative health effects. Thus ROSI offers significant opportunities to improve water quality and deliver social benefits such as improved health, if it can be implemented and operated sustainably in the different socia contexts of Central Australia.
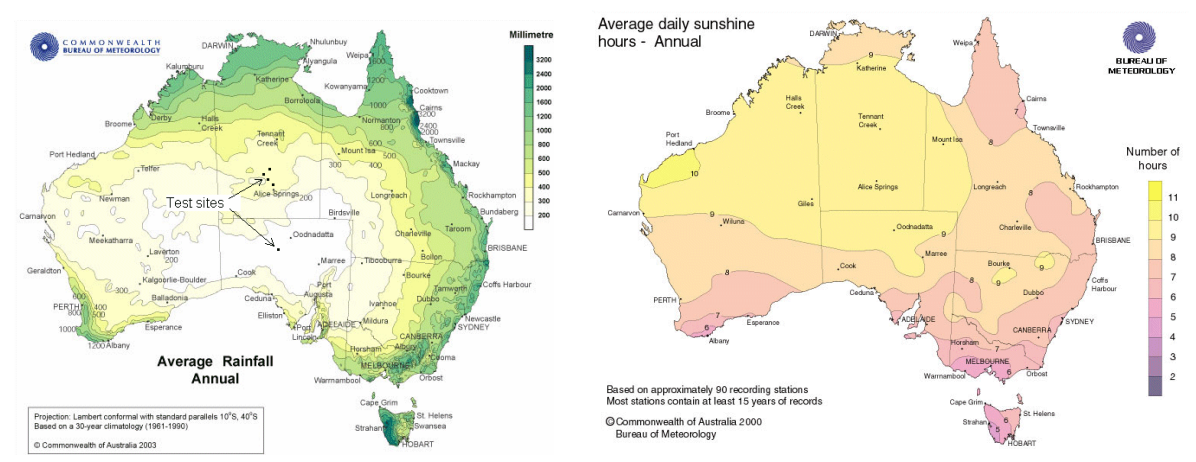

Figure 2. Map of average annual rainfall Figure 2. Map of average annual rai
$(\mathrm{mm})$ in Australia, provided by the Australian Government Bureau of Meteorology [16]. Test sithor.
marked by the author. Figure 3. Average annual sunshine hours
throughout Australia, provided by the Australian Government Bureau of Meteorology [17].

\subsection{The Reverse Osmosis Solar Installation (ROSI)}

ROSI is a small-scale desalination unit powered by solar energy [7-9], that combines ultrafiltration with reverse osmosis or nanofiltration to achieve the goals of turbidity removal, microbiological safety, desalination and trace contaminant removal [10]. Two $150 \mathrm{~W}$ solar panels provide the necessary power for a $300 \mathrm{~W}$ pump. No battery has been used in ROSI due to potential difficulties caused by batteries in remote situations.

The permeate flow for potable use is designed to be 400-1000 L/day [7], depending on the site and water needs. The flow of water disinfected by ultrafiltration was up to $4000 \mathrm{~L} / \mathrm{day}$. The recovery required to generate the desalinated permeate flow will also depend on the situation and water quality, but it is intended that the RO/NF system would run at low (brine) stream produced is still acceptable for non-potable uses such as showering, feed stock and toilet flushing. The suitability of low recovery operation and the resulting permeate and concentrate qualities are considered in relation to local water needs.

In October-November 2005, ROSI was taken to six sites in Central Australia for testing. These sites were chosen primarily on the basis of the poor bore water quality (the salinity, hardness and / or presence of trace contaminants), and were thus considered to be representative of the social contexts in which ROSI may ultimately be used. The different types of sites visited were: two farms, one roadhouse, two Indigenous communities and a small town. The location of these sites is shown in Figure 2.

\section{3 'Appropriate' and 'Sustainable' Technologies}

The concept of 'appropriate' technologies, developed by economist Schumacher in 1973 [18], suggests that the success of a technology is determined by its compatibility with the psychosocial (social) and biophysical (environmental) context in which it will be applied. The concept grew out of Schumacher's observations of the experiences of developing countries who received technologies from developed nations that were poorly suited to their needs and capabilities, resulting in premature failures which the recipients often ended up paying for. Beder [19] cites the examples of a nuclear power plant built in an earthquake-prone region of the Philippines, which had serious design flaws and has never operated but cost the Philippines a total of $\$ 2.3$ billion. Countless other examples of 'inappropriate' technologies can be found in the literature.

Later the concept of appropriate technology has been incorporated in 'sustainable technologies', which are defined as those technologies which are "compatible with or technologies', which are defined as those technologies which are "compatible with or
readily adaptable to the natural, economic, technical and social environment" [20]. Sustainable technologies are no longer limited to applications in developing countries, and expand the environmental and social focus of appropriate technology to incorporate economic and technical considerations. In this paper, ROSI's social sustainability will be examined by considering the unit's compatibility with, or ability to be adapted to, the socia environments in Central Australia. The factors which will play an important role in the social sustainability of such a unit are identified below. Further work in form of a scoping study is in progress to complete the list of factors.

\subsection{Social Aspects of Desalination and Renewable Energy Systems}

As noted above, the technical, economic and environmental aspects of small-scale renewable-powered desalination units have already received considerable attention whilst the social environments for which they are being suggested have been studied less closely. A review of the literature relating to small-scale desalination units highlights a number of attributes which have been identified as important contributors to their success and ongoing social sustainability. These can be summarised as the

- capacity of the unit to produce sufficient water quality and quantity to fulfil local needs [1, 21];

- capacity of the local community to construct (where appropriate), operate and maintain the unit [22, 23];

- ability of the unit to operate reliably and independently in a decentralised context [24];

- response of the community to the unit and thus it's ability to operate with minimal disruption caused to the local community [25].

Interestingly, many of these attributes are common to small-scale desalination systems in very diverse social settings, from rural communities in Egypt [23] to an Australian National Park [10]. However, whilst these attributes are often identified in the literature, the ability of systems to fulfil them is rarely critically analysed in light of the social context for which they have been developed or are most likely to be applied. This consideration of ROSl's ability to fulfil such criteria in Central Australia aims to help overcome this gap in the literature. Meerganz von Medeazza [26] concluded that desalination should not be used to supply water for activities that are not suited to arid environments, such as large-scale tourism or agriculture. Whilst small-scale units for groundwater desalination (such as ROSI) are likely to have less significant environmental impacts, the question of whether they contribute to basic water needs or inappropriate water usage in arid areas remains relevant, and can be answered by considering the volumes of water they produce in relation to social needs. Delyannis \& Belessiotis [6] identified mistakes made in the implementation of solar stills in 
a Greek Island. They noted that the operation of the stills by untrained operators and the absence of a regular maintenance plan contributed to their failure.

An examination of renewable energy (RE) power supply systems in remote areas should also provide some insights regarding the social sustainability of such technologies. A review of such systems in remote Australian communities found that inadequate maintenance support, caused by a lack of "effective trained personnel to maintain and service RE systems" [27, p. 51], was a major contributor to the failure or sub-optimum 作 operation of such systems. The distance of systems from service centres was also a problem, and a strong influence upon maintenance costs. Responses highlighted that pastoralists tended to be most concerned about the high costs of renewable energy systems, while Indigenous communities had concerns about their reliability. Some solutions suggested to these social issues include training programs for maintenance providers and accreditation for system installers, education about energy demand management for consumers, and the development of more reliable systems (hardware) [27].

\subsection{Evaluating Social Sustainability}

The focus of this research is thus upon determining whether a unit such as ROSI is likely to be socially sustainable in various Central Australian contexts. This will involve examining ROSI's compatibility with or ability to be adapted to relevant aspects of the social environment, such as:

- water quality and quantity needs

- the human resources available to operate and maintain such a unit, and

- the attitudes of community members to a prototype of ROSI.

This approach is illustrated schematically in Figure 4.

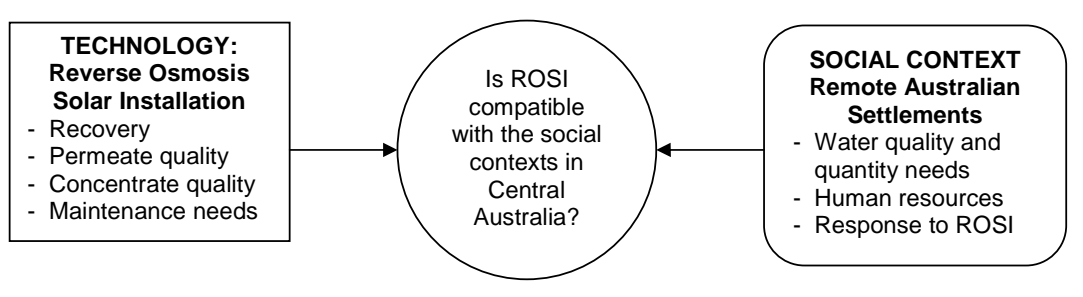

Figure 4. Schematic of approach to evaluate social sustainability.

\section{Methodology}

Two social science research methodologies were applied in this research. A general need for a unit such as ROSI has already been established, in terms of the limited rainfall and surface water sources available in Central Australia. Thus a case study approach using interviews and site visits was considered to be the best methodology for studying in greater detail the social aspects of water use and provision in different types of remote settlements [28]. The sect from community members about attitudes to ROSI via a questionnaire. Both methods are described in greater detail below.

\subsection{Case Study Context Analysis}

The first component of the research relates to determining ROSI's compatibility with social aspects of water use. As mentioned above, this requires a consideration of water quality and quantity needs, and the human resources available to operate and maintain the unit. A case study approach was taken, which involved examining the existing water provision mechanisms and interviewing the person responsible for the management of the existing water provision system at each site. In all cases this person had been exposed to ROSI by virtue of it having been operated at their site for a period of 2-10 days. They were shown the unit while it was functioning and had an opportunity to ask questions of engineers working on the project. These respondents were then interviewed about the following items:

- population at the site

- main socio-economic activities undertaken at the site

- existing water system, including the number and quality of bores available and other water sources

- shortfalls they observed in water quality and quantity

- responsibility for water system management, operation, maintenance and financing. By developing an understanding of these aspects of the water system at each site, an assessment of ROSI's potential compatibility can be made.

\subsection{Community Response to ROSI}

The second research activity relates to gathering the feedback of a range of people relating to ROSI. As mentioned above, a questionnaire was prepared to gather this feedback. The choice of a questionnaire rather than interviews was made because questionnaires are simpler to execute and allow for a greater number of responses to be gathered using fewer resources. The completion of a questionnaire in private also allows for unbiased information to be gathered by avoiding the interactions required with an interview, and when they are anonymous can encourage respondents to give more hones responses [29]. Thus in this project respondents filled out the questionnaire privately (on clipboards) and the responses given were anonymous. Participation in the completion of the questionnaire was voluntary

The knowledge of ROSI upon which respondents could base their answers was either a half-hour presentation about the unit, with an opportunity to ask questions at the end, or the operation of ROSI at their site again with the opportunity to ask questions of the engineers working on the project. At each test site and at a public seminar held in Alice Springs on Friday October $14^{\text {th }} 2005$ interested parties were invited to complete the questionnaire.

With the exception of the first question, the respondents could answer in their own words to explore the range of possible responses. The audience given the opportunity to respond included members of the general public, potential operators and users of the unit at each of the sites visited, representatives from resource management and water provision agencies, engineering consultancy firms and representatives from an Indigenous technology non-government organization (NGO). The topics covered by the questionnaire included the views of respondents regarding:

- their opinions of the combination of desalination and renewable energy (on a scale from poor to excellent)

- what they liked most about ROSI

- what they felt most needed to be improved about ROSI

- the situation / location in which they felt ROSI would be most useful

- their concerns (if any) about consuming water from ROS

- any other comments they wanted to make about ROSI.

By gathering responses to such questions, the community response to ROSI can be evaluated, which will contribute to a determination of its social sustainability. 
Werner, M. ; Schäfer, A. I. (2007) Social aspects of a solar-powered desalination unit for remote Australian communities, Desalination, Volume 203, Issues 1-3, 5 February 2007, Pages 375-393 doi:10.1016/j.desal.2006.05.008

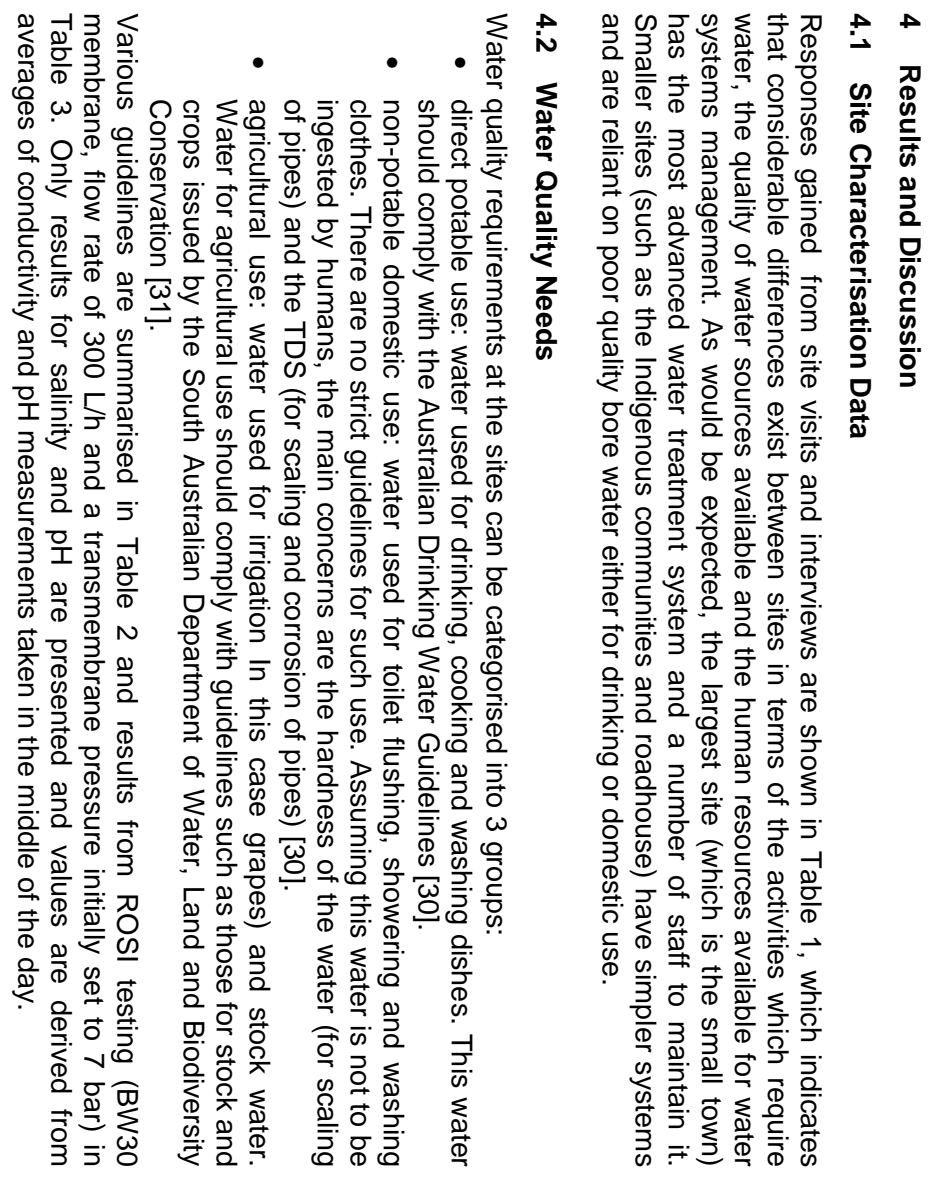

Table 1. Basic site data gathered from site visits and interviews (ESO: essential services officer).

\begin{tabular}{|c|c|c|c|c|c|c|}
\hline Site & Population & $\begin{array}{l}\text { Water Use } \\
\text { Activities }\end{array}$ & Water system & $\begin{array}{c}\text { Bore water } \\
\text { salinity }(g / L \\
\left.\text { TDS }^{1}\right)\end{array}$ & Quality \& Quantity Shortfalls & $\begin{array}{l}\text { Responsibility for } \\
\text { water system }\end{array}$ \\
\hline Grape Farm & $\begin{array}{l}\text { Up to } 50 \text { people at } \\
\text { harvest time for } 6- \\
8 \text { weeks, other- } \\
\text { wise } 5-7 \text { people. }\end{array}$ & $\begin{array}{l}\text { grape irrigation } \\
\text { domestic use }^{2}\end{array}$ & $\begin{array}{l}3 \times 10 \mathrm{~kL} \text { rainwater tanks } \\
\text { Drip irrigation system for } \\
\text { grapevines. } 5 \text { irrigation, } 1 \\
\text { domestic bore }\end{array}$ & 0.75 & $\begin{array}{l}\text { High hardness and nitrates in bore } \\
\text { water not ideal for grapes. } \\
\text { Rainwater for drinking is fine. } \\
\text { Quantity for all sources is OK. }\end{array}$ & Farm manager \\
\hline Cattle farm & $\begin{array}{l}\text { Up to } 20 \text { people } \\
\text { during cattle } \\
\text { mustering, other- } \\
\text { wise around } 5 \\
\text { people. }\end{array}$ & $\begin{array}{l}\text { stock water } \\
\text { domestic use }\end{array}$ & $\begin{array}{l}3 \text { rainwater tanks } \\
2 \text { water storage tanks } \\
5 \text { dams } \\
30 \text { bores for stock water } \\
\text { \& domestic use. }\end{array}$ & 4.8 & $\begin{array}{l}\text { One bore is on the limit of quality } \\
\text { acceptability for stock. Rainwater } \\
\text { for drinking is fine. } \\
\text { Quantity is generally OK, but } \\
\text { rainfall can be concentrated at one } \\
\text { time of the year. The main dam is } \\
\text { not always full. }\end{array}$ & Farm manager \\
\hline Roadhouse & $\begin{array}{l}6 \text { staff and up to } \\
40 \text { guests, } \\
\text { depending on the } \\
\text { season }\end{array}$ & $\begin{array}{c}\text { domestic \& } \\
\text { commercial use: } \\
\text { food preparation, } \\
\text { cleaning, } \\
\text { swimming pool \& } \\
\text { vehicle use. }\end{array}$ & $\begin{array}{l}\text { Multiple rainwater tanks, } \\
\text { storage tanks, piping. } \\
3 \text { bores for roadhouse \& } \\
\text { accommodation, } 1 \text { for } \\
\text { swimming pool. }\end{array}$ & 2.2 & $\begin{array}{l}\text { Bore water is unpalatable for } \\
\text { guests, so rain water is supplied. } \\
\text { Quantity is not always adequate. } \\
\text { The bores have low flows and can } \\
\text { run out. Lack of rainfall means } \\
\text { water has to be trucked at times. }\end{array}$ & $\begin{array}{c}\text { Roadhouse } \\
\text { manager }\end{array}$ \\
\hline $\begin{array}{c}\text { Indigenous } \\
\text { Community } \\
1\end{array}$ & $\begin{array}{l}\text { Usually } 20 \\
\text { residents, can } \\
\text { fluctuate due to } \\
\text { cultural reasons, } \\
\text { holidays etc. }\end{array}$ & domestic use & $\begin{array}{l}\text { Storage tank }(20 \mathrm{~kL}) \text { for } \\
\text { community needs. } \\
2 \text { bores for community } \\
\text { water supply. }\end{array}$ & 1.4 & $\begin{array}{l}\text { Quality is OK. } \\
\text { Quantity is also acceptable, as } \\
\text { long as the second bore is turned } \\
\text { on at night when the solar bore } \\
\text { switches off. }\end{array}$ & $\begin{array}{l}\text { Community council, } \\
\text { ESO and community } \\
\text { members }\end{array}$ \\
\hline $\begin{array}{l}\text { Indigenous } \\
\text { Community } \\
2\end{array}$ & $\begin{array}{l}40-50 \text { people on a } \\
\text { fairly constant } \\
\text { basis }\end{array}$ & domestic use & $\begin{array}{l}1 \text { rainwater tank for } \\
\text { drinking water. } \\
1 \text { bore for other water } \\
\text { needs. }\end{array}$ & 1.3 & $\begin{array}{l}\text { Residents complain about water } \\
\text { quality when showering. } \\
\text { Sometimes have to have water } \\
\text { trucked when rainfall is } \\
\text { inadequate. }\end{array}$ & $\begin{array}{l}\text { Community council, } \\
\text { ESO and community } \\
\text { members }\end{array}$ \\
\hline Town & $\begin{array}{l}3500 \text { permanent } \\
\text { population plus up } \\
\text { to } 1000 \text { tourists in } \\
\text { season }\end{array}$ & $\begin{array}{l}\text { domestic use } \\
\text { garden watering }\end{array}$ & $\begin{array}{l}1 \text { bore (high salinity) } \\
\text { provides water for } 2 \\
\text { reverse osmosis plants } \\
\text { which purify water from } \\
\text { for drinking. }\end{array}$ & $\begin{array}{l}\text { High salinity } \\
\text { bore } 15.6 \\
\text { Low salinity } \\
\text { bore } 4.1\end{array}$ & $\begin{array}{l}\text { Quality after RO is excellent. } \\
\mathrm{A} 2^{\text {nd }} \mathrm{RO} \text { plant was installed } 3 \\
\text { years ago to deal with quantity } \\
\text { shortfalls, and the situation now is } \\
\text { very good, consumers pay } \mathrm{A} \$ 5 / \mathrm{m}^{3}\end{array}$ & $\begin{array}{l}\text { Water Supply Dept. } \\
\text { of District Council } \\
\text { (manager plus four } \\
\text { staff). }\end{array}$ \\
\hline
\end{tabular}

\footnotetext{
${ }^{1}$ Total Dissolved Solids, converted from EC (electrical conductivity) measured at the site (0.55-0.60 TDS/EC derived from calibration measurements using NaCl).

${ }^{2}$ Domestic use refers to common water use activities in domestic situations such as drinking, cooking, washing clothes, cleaning, showering and toilet flushing.
} 
Werner, M. ; Schäfer, A. I. (2007) Social aspects of a solar-powered desalination unit for remote Australian communities,

Desalination, Volume 203, Issues 1-3, 5 February 2007, Pages 375-393

doi:10.1016/j.desal.2006.05.008

Table 2. Summary of water quality guidelines for different activities [30-33]

\begin{tabular}{|c|c|c|c|c|c|}
\hline Component & $\begin{array}{c}\text { Potable } \\
\text { use }\end{array}$ & $\begin{array}{c}\text { Domestic } \\
\text { non-potable } \\
\text { use }\end{array}$ & $\begin{array}{c}\text { Beef cattle } \\
\text { water }\end{array}$ & $\begin{array}{c}\text { Sheep } \\
\text { water }\end{array}$ & $\begin{array}{c}\text { Grape } \\
\text { irrigation } \\
\text { water }\end{array}$ \\
\hline TDS (g/L) & $0.5(\mathrm{a})$ & $1^{*}$ & 5 & 13 & 0.7 \\
\hline Nitrate $(\mathrm{mg} / \mathrm{L})$ & 100 & $\mathrm{~N} / \mathrm{A}^{3}$ & 400 & 400 & 30 \\
\hline Fluoride $(\mathrm{mg} / \mathrm{L})$ & 1.5 & $\mathrm{~N} / \mathrm{A}$ & 2.0 & 2.0 & 1.0 \\
\hline $\mathrm{pH}$ & $6.5-8.5$ & $6.5-9.5$ & $6.5-8.5$ & $6.5-8.5$ & $6.5-8.5$ \\
\hline Hardness $\left(\mathrm{mg} / \mathrm{L} \mathrm{CaCO} \mathrm{CaC}_{3}\right)$ & $200(\mathrm{a})$ & $200^{*}$ & $\mathrm{~N} / \mathrm{A}$ & $\mathrm{N} / \mathrm{A}$ & $>350$ \\
\hline Chloride $(\mathrm{mg} / \mathrm{L})$ & $250(\mathrm{a})$ & $\mathrm{N} / \mathrm{A}$ & $\mathrm{N} / \mathrm{A}$ & $\mathrm{N} / \mathrm{A}$ & 175 \\
\hline Boron $(\mathrm{mg} / \mathrm{L})$ & 4 & $\mathrm{~N} / \mathrm{A}$ & 5 & 5 & $0.5-1.0$ \\
\hline $\begin{array}{c}\text { Thermotolerant coliforms } \\
\text { (cfu/ } 100 \mathrm{~mL})\end{array}$ & 0 & 0 & $<100$ & $<100$ & $<1000$ \\
\hline Calcium $(\mathrm{mg} / \mathrm{L})$ & $\mathrm{N} / \mathrm{A}$ & $\mathrm{N} / \mathrm{A}$ & 1000 & 1000 & $\mathrm{~N} / \mathrm{A}$ \\
\hline Sulfate $(\mathrm{mg} / \mathrm{L})$ & $250(\mathrm{~h})$ & $500(\mathrm{a})$ & 1000 & 1000 & $\mathrm{~N} / \mathrm{A}$ \\
\hline Aluminium $(\mathrm{mg} / \mathrm{L})$ & 0.2 & 0.2 & 5 & 5 & 5 \\
\hline Copper $(\mathrm{mg} / \mathrm{L})$ & $1(\mathrm{a})$ & $2(\mathrm{~h})$ & 1 & 0.5 & 0.2 \\
\hline Iron $(\mathrm{mg} / \mathrm{L})$ & $0.3(\mathrm{a})$ & $3-4(\mathrm{p})$ & $\mathrm{N} / \mathrm{A}$ & $\mathrm{N} / \mathrm{A}$ & 0.2 \\
\hline Lead $(\mathrm{mg} / \mathrm{L})$ & $0.01(\mathrm{~h})$ & $\mathrm{N} / \mathrm{A}$ & 0.1 & 0.1 & 2 \\
\hline Manganese $(\mathrm{mg} / \mathrm{L})$ & $0.1(\mathrm{a})$ & $0.5(\mathrm{~h})$ & $\mathrm{N} / \mathrm{A}$ & $\mathrm{N} / \mathrm{A}$ & 0.2 \\
\hline Zinc $(\mathrm{mg} / \mathrm{L})$ & $3(\mathrm{a})$ & $\mathrm{N} / \mathrm{A}$ & 20 & 20 & 2 \\
\hline
\end{tabular}

(a) Refers to an aesthetic, $(\mathrm{h})$ refers to a health, $(\mathrm{p})$ refers to a practical guideline.

* It has been noted salinity greater than $1 \mathrm{~g} / \mathrm{L}$ TDS "may be associated with excessive scaling corrosion" [30, p.10-26] and when water has a hardness greater than $0.2 \mathrm{~g} / \mathrm{L}$ scaling of pipes becomes a problem.

Table 3. Water quality from ROSI during field trip solar experiments with BW30 membrane. TDS originally measured in EC units and converted using conversion factor $0.60 \mathrm{TDS} / \mathrm{EC}$ [31].

\begin{tabular}{|c|c|c|c|c|}
\hline \multirow{2}{*}{ Site } & \multicolumn{2}{|c|}{ Permeate } & \multicolumn{2}{c|}{ Concentrate } \\
\cline { 2 - 5 } & TDS (mg/L) & pH & TDS $\mathbf{( g / L )}$ & pH \\
\hline Grape Farm & 13 & 5.8 & 1.4 & 7.9 \\
\hline Cattle Farm & 112 & 7.5 & 6.1 & 8.1 \\
\hline Roadhouse & 79 & 7.1 & 3.0 & 8.2 \\
\hline $\begin{array}{c}\text { Indigenous } \\
\text { Community 1 }\end{array}$ & 25 & 6.4 & 2.3 & 8.4 \\
\hline $\begin{array}{c}\text { Indigenous } \\
\text { Community 2 }\end{array}$ & 27 & 5.8 & 2.2 & 8.0 \\
\hline $\begin{array}{c}\text { Town (low } \\
\text { salinity bore) }\end{array}$ & 146 & 7.3 & 5.1 & 8.1 \\
\hline
\end{tabular}

The results in Table 3 illustrate that the permeate salinity is suitable for potable water at all sites. Indeed, for sites such as Indigenous Community 1 and the Roadhouse, where people are accustomed to drinking water which currently exceeds the aesthetic salinity people are accustomed to drinking water which currently exceeds the aesthetic salinity
guideline, the introduction of a potable source with a significantly lower salinity (and thus different taste) may create acceptance issues. At these sites a different membrane with lower salt retention could be considered, such as a nanofiltration membrane like the NF90.

The permeate $\mathrm{pH}$ is lower than the recommended potable guideline at three sites - the grape farm and both indigenous communities. This could potentially lead to corrosion of pipes, depending on other factors such as the type of pipe and water temperature [30] It may also cause palatability issues. At these sites either the addition of an alkaline substance such as lime, or the use of a membrane with lower salt retention could be considered to increase the $\mathrm{pH}$ to a level suitable for potable consumption.
The concentrate salinities achieved do not meet the guideline of $1 \mathrm{~g} / \mathrm{L}$ TDS for non-potable domestic use at any site. However, given that the roadhouse is already using water with greater than $2 \mathrm{~g} / \mathrm{L}$ for non-potable use, the appropriateness of this guideline for Central Australia should be re-considered. As mentioned above, there is no strict limit for such use and the value has been derived based on the risk of scaling and corrosion of pipes at TDS $>1 \mathrm{~g} / \mathrm{L}$. This requires further investigation to determine if degradation of pipes is a major issue at sites such as the roadhouse.

At all sites the concentrate salinity is suitable for sheep stock consumption. It is suitable for beef with the exception of the cattle farm and the town. The low salinity recommended for grape irrigation means that the concentrate could not be used for this purpose at any site. The concentrate $\mathrm{pH}$ achieved at all sites is within the guidelines for domestic non-potable use. The upper limit of 9.5 has been applied to recognise that values above this "can irritate skin if the water is used for ablutions" [30, pH Fact Sheet].

\subsection{Water Quantity Needs}

The calculated water quantity needs at each site are shown in

Table 4. These figures are based upon the population estimates provided in the interviews and multiplied by the daily potable and non-potable water requirements.

Such requirements are difficult to quantify and will depend on a number of factors such as climate, physical activities undertaken, hygiene practices, available water source and other criteria [34]. A number of authors have attempted to determine how much water people need on a daily basis. Gleick suggests a minimum of $50 \mathrm{~L} / \mathrm{capita} /$ day $(\mathrm{L} / \mathrm{c} / \mathrm{d})$ based on 25 need on a daily basis. Gleick suggests a minimum of $50 \mathrm{~L} / \mathrm{capita} / \mathrm{day}(\mathrm{L} / \mathrm{c} / \mathrm{d})$ based on 25 L/c/d for potable purposes and sanitation needs plus an additional $25 \mathrm{~L} / \mathrm{c} / \mathrm{d}$ for bathing and cooking [34]. However it is noted that is less than a quarter of domestic use in Western
Europe, and less than a tenth of domestic use in the United States and Canada. In Australia, for two people sharing a suburban house with an average sized garden the seasonal average use recommended by Sydney Water is $184 \mathrm{~L} / \mathrm{c} / \mathrm{d}$ [35]. An investigation of water use in Indigenous communities found that daily use for drinking, cooking and washing dishes ranged from 30-66 L/c/d [36].

For the purposes of this calculation a figure of $30 \mathrm{~L} / \mathrm{c} / \mathrm{d}$ for potable water use has been applied, based on the figure quoted by Dorji for communities with a central pipe stand [37], which is the equivalent of the central distribution point found in most remote Australian communities. An allowance of $150 \mathrm{~L} / \mathrm{c} / \mathrm{d}$ for non-potable use is applied, based on an overall total of $180 \mathrm{~L} / \mathrm{c} / \mathrm{d}$ from the Sydney Water recommendations [35].

For agricultural use, ROSI is not designed to be the primary water source however it is necessary to examine whether the excess concentrate not used for domestic non-potable requirements could be applied for agricultural purposes, to prevent the need for other forms of disposal. For beef cattle an annual requirement of $17 \mathrm{~kL}$ is applied [38]. For grape irrigation at the farm visited the permitted water use for irrigation is $10 \mathrm{ML} /$ hectare $^{4}$ and the

area planted with grapes is approximately 160 hectares.
ROSl's annual production of permeate and concentrate at each site are shown in Table 5 . Again, these figures are based on solar experiments carried out with a BW-30 membrane as described above. However, these results have been determined from only one day of testing at each bore and further data on long-term performance is required to confirm results. There are on average 63.5 cloudy days each year in the region of Central Australia visited [39], so the daily production measured during the solar experiments has been multiplied by 300 days. For the town site, it has been assumed that ROSI would be scaled up by a factor of 250 to deliver the required water quantity for this location.

${ }^{4}$ A hectare is a metric unit of area equal to $10000 \mathrm{~m}^{2}$. 
Werner, M. ; Schäfer, A. I. (2007) Social aspects of a solar-powered desalination unit for remote Australian communities,

Desalination, Volume 203, Issues 1-3, 5 February 2007, Pages 375-393

doi:10.1016/j.desal.2006.05.008

Table 4. Calculated annual water quantity needs at each site

\begin{tabular}{|c|c|c|c|c|c|c|}
\hline Site & $\begin{array}{c}\text { Permanent } \\
\text { population }\end{array}$ & $\begin{array}{c}\text { Temporary } \\
\text { population }\end{array}$ & $\begin{array}{c}\text { No. of } \\
\text { weeks }\end{array}$ & $\begin{array}{c}\text { Total annual } \\
\text { potable } \\
\text { needs (kL) }\end{array}$ & $\begin{array}{c}\text { Total annual } \\
\text { non-potable } \\
\text { needs (kL) }\end{array}$ & $\begin{array}{c}\text { Annual } \\
\text { agricultural } \\
\text { needs (kL) }\end{array}$ \\
\hline Grape Farm & 6 & 50 & 7 & 139 & 696 & 160,000 \\
\hline Cattle Farm & 5 & 20 & 10 & 97 & 484 & 85,000 \\
\hline Roadhouse & 6 & 30 & 15 & 160 & 801 & $\mathrm{~N} / \mathrm{A}$ \\
\hline $\begin{array}{c}\text { Indigenous } \\
\text { Community 1 }\end{array}$ & 20 & 20 & 10 & 261 & 1305 & $\mathrm{~N} / \mathrm{A}$ \\
\hline $\begin{array}{c}\text { Indigenous } \\
\text { Community 2 }\end{array}$ & 45 & 0 & 0 & 493 & 2464 & $\mathrm{~N} / \mathrm{A}$ \\
\hline Town & 3500 & 1000 & 10 & 40425 & 202125 & $\mathrm{~N} / \mathrm{A}$ \\
\hline
\end{tabular}

Table 5. ROSI permeate and concentrate quantity produced at each site

\begin{tabular}{|c|c|c|c|c|c|}
\hline Site & $\begin{array}{c}\text { Total annual } \\
\text { permeate } \\
\text { flow (kL) }\end{array}$ & $\begin{array}{c}\text { Total annual } \\
\text { concentrate } \\
\text { flow (kL) }\end{array}$ & $\begin{array}{c}\% \text { of Total } \\
\text { annual pot- } \\
\text { able needs }\end{array}$ & $\begin{array}{c}\% \text { of Total } \\
\text { annual non- } \\
\text { potable needs }\end{array}$ & $\begin{array}{c}\text { Recovery } \\
\text { (\%) }\end{array}$ \\
\hline Grape Farm & 591 & 635 & 425 & 91 & 48 \\
\hline Cattle Farm & 286 & 826 & 296 & 171 & 26 \\
\hline Roadhouse & 302 & 559 & 189 & 70 & 35 \\
\hline $\begin{array}{c}\text { Indigenous } \\
\text { Community 1 }\end{array}$ & 537 & 640 & 206 & 49 & 46 \\
\hline $\begin{array}{c}\text { Indigenous } \\
\text { Community 2 }\end{array}$ & 456 & 672 & 93 & 27 & 40 \\
\hline Town & 68,985 & 305,235 & 122 & 108 & 18 \\
\hline
\end{tabular}

ROSI is capable of producing enough permeate to meet the annual potable water needs at all sites except the second Indigenous community, where it is still close at $93 \%$ of annual needs. ROSI produces too much permeate at the cattle and grape farms, the roadhouse and Indigenous Community 1 for current requirements. At the grape farm, roadhouse and Indigenous Community 1 this could be overcome by reducing the recovery to increase the percentage of non-potable needs met. Alternatively, permeate could be put to use for nonpotable domestic uses. At the cattle farm excess permeate could also be used for nonpotable purposes or for stock water. At all sites except the cattle farm, the amount of concentrate produced by ROSI is not sufficient to meet all domestic non-potable needs cond there is no intention as those needs co and there is no intention as those needs can be supplemented with bore water.

Overall, these results suggest that the quantity of permeate produced by ROSI is higher than required and hence a lower recovery would increase the balance between potable and non-potable water supplied.

\subsection{Human Resources Available for Operation and Maintenance}

As was shown in Table 1, at each site the responsibility for the water system lies with either the site manager or, in the case of the Indigenous communities, an essential services officer (ESO). In the case of the town there is a team of 5 staff responsible for water system. These people all have a good level of knowledge about bores, pumps, and water storage and distribution systems. They carry out the day-to-day maintenance of the system and call specialists when a greater level of expertise is required. One farm manager mentioned a familiarity with membrane filtration systems, although he hadn't used his small unit for a number of years. None of the other site managers or ESOs had any experience with membrane filtration systems. All staff at the town are familiar with the any experience with membrane filtration systems. All staff at
operation and maintenance of a membrane filtration system.

In terms of familiarity with solar power systems, at both the pastoral lease and roadhouse there were solar hot water systems installed. However the pastoral lease owner expressed frustration with the ability of the solar system to provide adequate hot water and he had for this reason reverted back to conventional power for his hot water system. The actual reason for this problem was not identified. At one of the indigenous communities there was a solar bore pump and at the other there were a number of solar panels providing electricity for the public phone as well as residential needs. This suggests that there is at least a basic familiarity with solar power provision at four out of the six sites.

The existing knowledge of membrane filtration systems amongst the people with responsibility for the water systems is not likely to be adequate to support the functioning of ROSI at all sites except for the small town. However, this does not necessarily mean that ROSI is incompatible with the human resources available. If the necessary skills and knowledge could be imparted to the person responsible for the water system at each site, knowledge could be imparted to the person responsible for the water system at each site,
and if a higher level of expertise were available as back-up when complicated problems occurred, then ROSI could be able to be operated without any significant extra burden being placed upon the people responsible for the water system. It is interesting that the people of the town are paying for water provision and this payment covers the costs not only to produce the water, but also to employ four staff to maintain the system. Such a model plays an important role in the provision of high quality water but requires modification for a small community situation. The knowledge and skills required for day-today operation and periodic maintenance (in areas such as membrane cleaning, prevention of fouling, maintaining general system performance and service) could be delivered via an of fouling, maintaining general system performance and service) could be delivered via an
initial training session when the unit was delivered, and supported with a reference guide or troubleshooting manual provided with the unit when sold. In terms of additional expertise for more complicated problems, the regional centre of Alice Springs is home to a number of tradesmen and contractors, who could provide additional expertise required either over the phone or by travelling to the site if necessary. A considerable level of familiarity with solar power for hot water systems or energy provision, so minimal additional training would be required. The use of the solar tracker may require some training, as the existing solar power systems are stationery. Major system failures that require spare parts and trained personnel will be a major management issues due to the require spare parts and trained personnel will be a major management issues due to the
remoteness of the locations, the probability of such failures, and their likely duration needs to be offset with adequate water storage.

\subsection{Community Response to ROSI}

Of an estimated forty people who saw ROSI in the field or attended the seminar and thus had an opportunity to complete the questionnaire, ten responses were received. These responses are summarised in Table 6 . The sum of responses may be greater than ten in cases where respondents included two items in their answers - for example in response to items 2 and 3 about likes and dislikes some respondents listed more than one item. 
Werner, M. ; Schäfer, A. I. (2007) Social aspects of a solar-powered desalination unit for remote Australian communities,

Desalination, Volume 203, Issues 1-3, 5 February 2007, Pages 375-393

doi:10.1016/j.desal.2006.05.008

The low response rate of $25 \%$ (mostly due to the informal nature of the surveys) means that it is not possible to draw any statistical inferences about whether or not the views of the broader community are represented in the responses. Because the organiser of the surveys was also clearly a member of the research team, respondents who had negative opinions about ROSI may have held back from completing the survey, leading to the possibility of positive bias in the responses received. Nonetheless, the responses are still of interest for the range of issues they raise and contribute to the larger scale scoping study for a more formal survey process.

study for a more formal survey process. All respondents rated the combination of desalination and renewable energy as either
'good' or 'excellent'. This suggests that the concept behind ROSI was viewed positively by the respondents, although a much wider survey would be required to confirm that this indicates a high level of community support for the concept.

The practicality and small size of ROSI were viewed as the 'most liked' features of ROSI. This suggests that respondents felt positive about the potential for the application of desalination combined with renewable energy to water problems facing small remote communities.

The most common aspects of ROSI that respondents felt needed improvement were related to ongoing maintenance and the consistency of the power supply. With respect to related to ongoing maintenance and the consistency of the power supply. With respect to
maintenance, comments were made about the limitations of local services and the need to maintenance, comments were made about the limitations of local services and the need to
have an established maintenance procedure and responsibilities. As was seen above, have an established maintenance procedure and responsibilities. As was seen above, knowledge of membrane systems in the remote communities visited is limited, and both training and support would be required by those responsible for the water systems where ROSI was purchased. A solar power project called 'Bushlight' [40] that has been run by the Centre for Appropriate Technology (CAT) in Alice Springs provides some insights as to how technology can be managed in remote settlements for sustainability. In communities that participate in the program, which delivers household renewable energy systems, community members are trained in the basic maintenance and operation of the system community members are trained in the basic maintenance and operation of the system
when it is installed [40]. In the first year in which the solar power system is operational, when it is installed [40]. In the first year in which the solar power system is operational,
Bushlight staff provide support (both additional training and technical support) for community members and the staff member from the community council or resource agency who is responsible for system maintenance. At the end of the first year, Bushlight staff carry out a review of the system which highlights any shortfalls in community satisfaction or maintenance support so that these can be addressed. They stay in touch after this review but the goal is for the system to be sustained by the community itself. $A$ Indigenous communities, although funding for such a program would obviously be an issue. Whilst communities who participate in Bushlight contribute to the cost of their system, extra funding of $\$ 8.4$ million over four years is provided by the Australian Greenhouse Office.

In terms of the solar power supply, some respondents expressed concerns about not having any water output when there was no sun. However, the calculations above, which are based on climatic data gathered over a number of years by the Bureau of Meteorology, suggest that the annual production of ROSI will be adequate to supply community needs. If an extended bad weather period occurred, there is the possibility of running ROSI from a conventional power source (such as a high quality diesel generator) to provide clean water. Thus consideration needs to be given to including a generator as an emergency back-up when ROSI is supplied, or ensuring that the site has an existing generator that is adequate and could be used in such a situation if water storage is not sufficient. It would also have to be included in system training how to operate the generator to power ROS during extended cloud coverage.

Remote Indigenous communities were seen as being the locations where ROSI would be most useful. This suggests that there exists a genuine need and desire for a unit such as 
Werner, M. ; Schäfer, A. I. (2007) Social aspects of a solar-powered desalination unit for remote Australian communities,

ROSI, although again this would need to be confirmed in a larger survey. Farms and developing countries were each mentioned by a single respondent.

Most respondents appeared to be confident about the quality of water from ROSI being suitable for drinking; however confirmation of quality was raised by others as an issue of concern before they would be willing to drink it. This may be due to a lack of familiarity with the technology or negative perceptions held in some Indigenous communities that the water from rever needs to be explored in greater depth but could potentially be overcome by demonstrating the technology and using test results to prove its capabilities. For example, maintenance of the unit and unknown water quality were both mentioned by respondents. Poor maintenance should not significantly affect permeate quality but may affect the quantity produced. Essentially if there is water coming out of the unit it will be safe to drink, but a greater level of community awareness and acceptance would be required to build trust in people that this was indeed the case. Clearly longer term demonstration and provision of water quality data will help this cause.

For the last question respondents were asked if they would like to make any other comments. The comments made reflected a number of concerns. One respondent suggested that there is a considerable market for the product in Western NSW, and another remarked on ROSl's "huge" potential to deliver clean drinking water to communities who need it. Research has demonstrated that such communities will also be found overseas in countries such as Turkey, Morocco, Jordan, Egypt and Cyprus [41] Another respondent again highlighted the need for the unit to be easy to operate for people not familiar with desalination, and another questioned the presence of essentia trace elements in permeate from reverse osmosis units. This latter point will be examined when further water quality results from the field trip are available.

Overall, the results of this survey suggest that the response to ROSI is generally positive, although further work is required identify issues with a larger group of respondents. The concerns raised by respondents related primarily to the maintenance of the unit and the consistency of its power supply.

Maintenance and operation of ROSI in remote areas could be supported by following a model similar to that used by the Bushlight program. Further testing is also required to determine ROSI's maintenance requirements in a situation of long term use and ongoing work will explore those issues in more detail.

\section{Conclusions and Recommendations}

This research has highlighted a number of factors that need to be considered when attempting to evaluate the social compatibility and sustainability of a water technology such as ROSI. In drawing conclusions in must be noted that the results in this paper refer so there is still considerable ability for the unit to be adapted to better meet social needs. This adaptability is, in itself, an important factor in the overall sustainability of the unit.

In relation to water quality, the permeate produced by ROSI is of very low salinity and this is not necessarily optimum for social acceptance due to the difference in salinity from previous water sources (at some sites) and the low $\mathrm{pH}$. Investigation of the performance of different membranes have been undertaken (results not presented here) to seek a membrane with lower salt retention. As for large scale unis, $\mathrm{pH}$ adjustment of the permeate may also need to be considered if the $\mathrm{pH}$ does remain below the guideline value. Mixing of bore water with permeate to address both those issues is a further option to be considered in some locations.

The use of concentrate is also subject of further investigations; however this should be carried out in respect to a suitable salinity guideline to apply for domestic non-potable water use in Central Australia.
In relation to water quantity, the recovery used in the solar experiments were higher than necessary to meet the potable needs of most sites. Reducing recoveries would not only better match permeate production with water needs, it would also reduce the salinity of the concentrate.

For ROSI to be operated and maintained to ensure its sustainability, training is likely to be required at all sites (with the exception of the town which already has an RO system) Further investigation of a possible model for higher-level support and supply of spare parts is required and the Bushlight project could be used as an example.

ROSI was generally perceived positively by the questionnaire respondents, indicating good potential for acceptance by communities. However the validity of this conclusion is limited by the number of responses and greater involvement of possible recipient communities is required. A number of issues were raised by respondents which are valid concerns and should be addressed in information about or demonstrations of ROSI.

Thus it can be concluded that the prototype of ROSI used on the field trip has demonstrated the potential to be a socially sustainable water technology in remote areas of Central Australia. A number of recommendations for design and technology management have been made which will help to ensure that this potential is fulfilled.

\section{Acknowledgements}

The support of the Australian Government through the provision of an Australian Postgraduate Award, and of the CSIRO 'Water for a Healthy Country' National Research Flagship and the Desert Knowledge Co-operative Research Centre are gratefully acknowledged. The other field trip participants are also thanked for their assistance, patience and hard work: Andreas Broeckmann, Bryce Richards, Kai Ratte, Thomas Kruttschnitt and Philipp Sausele. The overall ROSI project is funded through the Australian Research Council Linkage Project LP0349322 in collaboration with Mono Pumps Australia. John Childs (Northern Territory Power and Water; CRC Desert Knowledge) is thanked for his support with bore water quality data and desert logistics. The authors would like to thank the field trial sponsors BP Solar (Australia), GHD Pty. Ltd (Water Group, Brisbane), Department of Environment and Heritage, New South Wales Department of Commerce, and the Australian National University.

\section{References}

1. Tzen, E., K. Perrakis, and P. Baltas, Design of a stand alone PV - desalination system for rural areas. Desalination, 1998. 119(1-3): p. 327-333.

2. Weiner, D., D. Fisher, E.J. Moses, B. Katz, and G. Meron, Operation experience of a solar- and wind-powered desalination demonstration plant. Desalination, 2001. 137: p. 7-13.

3. Herold, D., V. Horstmann, A. Neskakis, J. Plettner-Marliani, G. Piernavieja, and R. Calero, Small scale photovoltaic desalination for rural water supply - demonstration plant in Gran Canaria. Renewable Energy, 1998. 14(1-4): p. 293-298.

4. UNDP. UNDP and Water. United Nations Development Program, [cited 1/3/06]; Available from: http://www.undp.org/water/index.html.

5. Schäfer, A. and B. Richards, Membranes and renewable energy - a new era of sustainable development for developing countries. Membrane Technology, 2005. sustainable development for developing countries. Membrane Technology, 2005. Delyannis, E.E. and V. Belessiotis, Solar application in desalin
Islands experiment. Desalination, 1996. 100(1-3): p. 27-34.

. Richards, B.S. and A.I. Schäfer, Design considerations for a solar-powered desalination system for remote communities in Australia. Desalination, 2002. 144: p. 193-199. 
Werner, M. ; Schäfer, A. I. (2007) Social aspects of a solar-powered desalination unit for remote Australian communities,

Desalination, Volume 203, Issues 1-3, 5 February 2007, Pages 375-393

doi:10.1016/j.desal.2006.05.008

8. Richards, B.S. and A.I. Schäfer, Photovoltaic-powered desalination system for remote Australian communities. Renewable Energy, 2003. 28: p. 2013-2022.

9. Masson, L., B.S. Richards, and A.I. Schäfer, System design and performance testing of a hybrid membrane-photovoltaic desalination system. Desalination, 2005. 179(1-3): p. 51-59.

10. Schäfer, A.I. and B.S. Richards, Testing of a hybrid membrane system for groundwater desalination in an Australian national park. Desalination, 2005. 183(13): p. 55-62.

11. Commonwealth Department of Health and Aged Care, Measuring Remoteness: Accessibility/Remoteness Index of Australia (ARIA), Revised Edition. 2001: Canberra.

12. ABS. How many people live in Australia's remote areas? Australian Bureau of Statistics, 2004 [cited 7/2/06]; Available from: http://www.abs.gov.au/Ausstats/abs@.nsf/Previousproducts/1301.0Feature\%20Arti cle22004 ?opendocument\&tabname $=$ Summary\&prodno $=1301.0$ \&issue $=2004 \&$ num $=$ \&view $=$.

13. $\mathrm{ABS}$, Housing and Infrastructure in Aboriginal and Torres Strait Islander Communities Australia 2001. 2002, Australian Bureau of Statistics: Canberra.

14. Australasia Economics, Key Social and Economic Indicators for Indigenous Australia: A Comparative Analysis. 2004, Office of Aboriginal and Torres Strait Islander Affairs: Canberra.

15. Willis, E., M. Pearce, T. Jenkin, S. Wurst, and C. McCarthy, Water Supply and Use in Aboriginal Communities in South Australia. 2004, Department for Aboriginal Affairs and Reconciliation: Adelaide.

16. BOM. Average Annual Rainfall. Bureau of Meteorology, 2003 [cited 24/3/06];

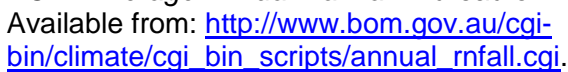

17. BOM. Average daily sunshine hours - Annual. Bureau of Meteorology, 2000 [cited 10/11/2005]; Available from:

http://www.bom.gov.au/climate/averages/climatology/sunshine hours/map gifs/ann ual.shtml.

18. Schumacher, E.F., Small is Beautiful: A Study of Economics as if People Mattered. 1973, London: Blond and Briggs Ltd.

19. Beder, S., The Nature of Sustainable Development. 1993, Newham, Victoria: Scribe Publications Limited.

20. Balkema, A.J., H.A. Preisig, R. Otterpohl, and F.J.D. Lambert, Indicators for the sustainability assessment of wastewater treatment systems. Urban Water, 2002. 4: p. $153-161$.

21. Bouguecha, S., B. Hamrouni, and M. Dhahbi, Small scale desalination pilots powered by renewable energy sources: case studies. Desalination, 2005. 183: $\mathrm{p}$. 151-165.

22. Bouchekima, B., A solar desalination plant for domestic water needs in arid areas of South Algeria. Desalination, 2003. 153(1-3): p. 65-69.

23. Fath, H.E.S., F.M. El-Shall, G. Vogt, and U. Seibert, $A$ stand alone complex for the production of water, food, electrical power and salts for the sustainable development of small communities in remote areas. Desalination, 2005. 183(1-3): $p$. 13-22.

24. Ayoub, J. and R. Alward, Water requirements and remote arid areas: the need for small-scale desalination. Desalination, 1996. 107(2): p. 131-147.

25. Robinson, R., G. Ho, and K. Mathew, Development of a Reliable Low-Cost Reverse Osmosis Desalination Unit for Remote Communities. Desalination, 1992. 86: p. 926.
26. Meerganz von Medeazza, G.L., "Direct" and socially-induced environmental impacts of desalination. Desalination, 2005. 185(1-3): p. 57-70.

27. Lloyd, B., L. Wilson, and D. Lowe, Renewable Energy in Remote Australian Communities (A Market Survey): Final Report. 2000, Australian CRC for Renewable Energy Ltd: Perth.

28. Patton, M.Q., Qualitative Evaluation and Research Methods. 2nd ed. 1990, California: Sage Publications.

29. Hoyle, R.H., M.J. Harris, and C.M. Judd, Research Methods in Social Relations. 7th ed. 2002, London: Wadsworth Thomson Learning.

30. NHMRC, Australian Drinking Water Guidelines 6. 2004, National Health and Medical Research Council: Canberra.

31. DWLBC. Salinity of Groundwater in SA. Department of Water Land and Biodiversity Conservation, 2004 [cited 8/11/2005]; 4]. Available from: http://www.dwlbc.sa.gov.au/files/FS32Mk4.pdf.

32. Markwick, G. Water requirements for sheep and cattle. New South Wales Department of Primary Industries, 2002 [cited 1/3/06]; Available from: http://www.agric.nsw.gov.au/reader/water-livestock/a054.htm.

33. Australian and New Zealand Environment and Conservation Council (ANZECC) and Agriculture and Resource Management Council of Australia and New Zealand (ARMCANZ). Australian and New Zealand Guidelines for Fresh and Marine Water Quality. Department of the Environment and Heritage, 2000 [cited 11/4/06]; Volume 3 , Primary Industries - Rationale and Background Information (Chapter 9)]. Available from: http://www.deh.gov.au/water/quality/nwams/volume3.html.

34. Gleick, P.H., The World's Water 1998-1999: The Biennial Report on Freshwater Resources. 1998, Washington: Island Press.

35. Sydney Water. How much water did your household save? Sydney Water, 2005 [cited 12/4/06]; Available from:

h. http://www.sydneywater.com.au/SavingWater/InYourHome/Saved Display.cfm. Yuen, E., G. Ho, M. Anda, K. Clarkson, and D. Day. Water usage in Australian indigenous communities. in 29th WEDC International Conference: Towards the Millenium Development Goals. 2003. Abuja, Nigeria: Water Engineering Development Centre.

37. Dorji, T., Advanced Water Treatment for Remote Communities: Application of Membrane Technology to Mountainous Areas. 2004, University of Wollongong. p. 91.

38. DPI Victoria. Water use and storage on farms. Victorian Department of Primary Industries, 2004 [cited 29/3/06].

39. BOM. Climate Averages for Australian Sites - Averages for ALICE SPRINGS AIRPORT. Bureau of Meteorology, 2004 [cited 29/3/06]; Available from: http://www.bom.gov.au/climate/averages/tables/cw 015590.shtml.

40. West, G., Community planning to deliver better outcomes, in Our Place. 2004 Centre for Appropriate Technology. p. 6-9.

41. Papapetrou, M., C. Epp, S. Teksoy, S. Sozen, V.S. Ortin, U. Seibert, and G. Vogt, Market analysis for Autonomous Desalination Systems powered by renewable energy in southern Mediterranean countries: Case study on Turkey. Desalination, 2005. 183: p. 545-556. 